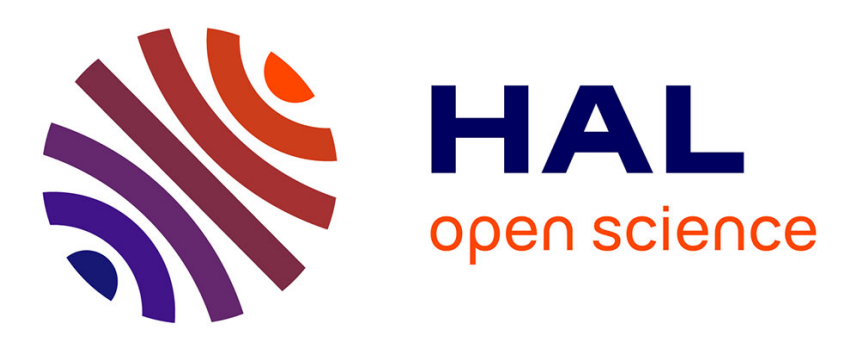

\title{
Roe deer (Capreolus capreolus L.) browsing effects and use of chestnut and Turkey oak coppiced areas
}

\author{
Cutini, Bongi, Chianucci, Pagon, Grignolio, Amorini, Apollonio
}

\section{To cite this version:}

Cutini, Bongi, Chianucci, Pagon, Grignolio, et al.. Roe deer (Capreolus capreolus L.) browsing effects and use of chestnut and Turkey oak coppiced areas. Annals of Forest Science, 2011, 68 (4), pp.667-674. 10.1007/s13595-011-0072-4 . hal-00930805

\section{HAL Id: hal-00930805 https://hal.science/hal-00930805}

Submitted on 1 Jan 2011

HAL is a multi-disciplinary open access archive for the deposit and dissemination of scientific research documents, whether they are published or not. The documents may come from teaching and research institutions in France or abroad, or from public or private research centers.
L'archive ouverte pluridisciplinaire HAL, est destinée au dépôt et à la diffusion de documents scientifiques de niveau recherche, publiés ou non, émanant des établissements d'enseignement et de recherche français ou étrangers, des laboratoires publics ou privés. 


\title{
Roe deer (Capreolus capreolus L.) browsing effects and use of chestnut and Turkey oak coppiced areas
}

\author{
Andrea Cutini • Paolo Bongi • Francesco Chianucci • \\ Nives Pagon - Stefano Grignolio • Emilio Amorini • \\ Marco Apollonio
}

Received: 8 July 2010 / Accepted: 30 January 2011 /Published online: 2 June 2011

(C) INRA and Springer Science+Business Media B.V. 2011

\begin{abstract}
- Introduction Roe deer (Capreolus capreolus) browsing pressure on vegetative regeneration of Turkey oak (Quercus cerris) and chestnut (Castanea sativa) and roe deer use of coppiced areas were investigated.

- Methods In the Apennines, Central Italy, six experimental areas were chosen, where fenced (ungulate access excluded, protected $\mathrm{P}$ ) and non-fenced (ungulate influence present, non-protected NP) plots were established after coppicing. From 2002 to 2005, each plot was surveyed twice a year, and number, biomass, collar diameter, and total height of the sprouts were measured.

- Results Roe deer had a different effect on the re-growth of Turkey oak and chestnut sprouts. After 4 years, chestnut did not show any browsing-related damage, while in Turkey oak, biomass and height of the sprouts in fenced plots significantly differed from those in non-fenced plots. The results agreed with an experimental browsing index. The outcome is relevant because it represents a quick and reliable field tool to assess the impact on a larger scale, where analytic and quantitative approaches cannot be applied. The locations of 62 adult radiocollared roe deer confirmed an increase in the use of coppiced areas. A utilisation index showed more frequent use of these
\end{abstract}

Handling Editor: Matthias Dobbertin

A. Cutini $(\bowtie) \cdot F$. Chianucci $\cdot$ E. Amorini

CRA-SEL, Forestry Research Centre-Agricultural Research

Council,

Viale Santa Margherita 80,

52100 Arezzo, Italy

e-mail: andrea.cutini@entecra.it

P. Bongi $\cdot$ N. Pagon $\cdot$ S. Grignolio $\cdot$ M. Apollonio Department of Zoology and Evolutionary Genetics,

University of Sassari,

Via Muroni 25,

07100 Sassari, Italy areas during and after forest work. Contrary to common opinion, logging seemed to attract roe deer in coppiced areas as the vegetation biomass at their disposal increased.

\section{Keywords Castanea sativa $\cdot$ Coppice $\cdot$ Deer $\cdot$ Forest damages $\cdot$ Quercus cerris}

\section{Introduction}

Over the last few decades, the relationships between wild ungulates and forest ecosystems have been investigated in depth by means of different methods that have focused on the complexity of interactions between fauna and forest vegetation (Jorritsma et al. 1999; Reimoser et al. 1999; Partl et al. 2002). This has been a particularly relevant issue in Europe and specifically in Italy, where since the last century, dramatic social changes in rural as well as mountainous areas have resulted in the progressive abandonment of crop lands, fallows, and hayfields and, consequently, into a marked forest expansion (Bätzing et al. 1996; Höchtl et al. 2005). Over the last two decades, the total surface of forested areas in Italy increased from 8.6 to 10.5 million hectares (INFC 2007). On the other hand, silvicultural systems and practices, shaped according to natural processes and functions within the forest ecosystem and oriented towards a sustainable forest management, became more and more common. In addition, since the 1980s, the total surface of protected forested areas in Italy noticeably increased thanks to the establishment of many national and regional parks. These processes resulted in the decline of overall wood exploitation and improved productivity and structural complexity of forest ecosystems.

Among the consequences of this relevant ecological change was the development of favourable conditions for 
the natural increase and reintroduction of large mammals. This was the case of wild ungulates, which were often regarded as rare species until the 1970s and that experienced a significant increase in population density in the last 30 years: roe deer (Capreolus capreolus) populations in Italy increased by $300 \%$ (Apollonio et al. 2010). As a consequence, negative impacts in forestry and agriculture became more and more frequent, and the need for an integrated management of deer and forests dramatically increased (Cutini 2006).

Also, in other European countries, ungulate populations reached high densities (Latham 1999), which was claimed to promote a decrease in habitat suitability in the long run (Tremblay et al. 2007) and to threaten indirectly the sustainability of deer populations themselves through the strong depletion of food resources (Forsyth and Caley 2006). Moreover, silvicultural practices were found to be unlikely to restore natural regeneration as long as the presence of deer populations at high densities persisted (Beguin et al. 2009).

The browsing effects vary to a substantial degree according to deer density (Gill 1992; Reimoser et al. 1999), environmental factors, and natural resource management such as the silvicultural techniques, which are meant to design the spatial and temporal distribution of resources (Morellet and Guibert 1999; Mysterud and Ǿstbye 1999; Putman 1994; Morellet et al. 2007; Reimoser and Ellenberg 1999). In fact, a high degree of variability in browsing intensity was also reported among separate sub-sampling areas, which reflected high temporal (seasonality) and spatial (microclimate, vegetation communities etc.) variability of biotic and abiotic factors on a local scale (Bergquist et al. 2003; Jarni et al. 2004). Therefore, it is advisable to define the relationships between browsing pressure and damage for each habitat and management practice, in order to be able to predict browsing effect variations due to changes in the demographic characteristics of ungulate populations and/or changes in forestry management practices.

Some studies found that deer browsing had a strong effect on forest restoration, reducing plant size and changing biomass distribution (Partl et al. 2002; Drexhage and Colin 2003), and regeneration under different management regimes (Beguin et al. 2009). The estimate of browsing damage is a very complex issue (Canham et al. 1993; Reimoser et al. 1999) that was more frequently explored in relation to conifer species (Welch et al. 1991; Gill 1992; Mysterud and Ǿstbye 2004) than in the poorly investigated, broadleaf species (Kay 1993; Putman 1994). In addition, the use of clear-cut areas by deer is an important and not adequately documented factor both for forest and game management (Cooke and Lakhani 1996; Joys et al. 2004).

The aim of this study was to assess the effects of roe deer population on vegetative regeneration of two broadleaved tree species in coppiced areas, in order to gain a better understanding of the interactions between coppice forests and roe deer spatial behaviour in Apennine forest ecosystem. In particular, we analysed the effect of roe deer browsing on vegetative regeneration of Turkey oak (Quercus cerris) and chestnut (Castanea sativa), two of the most important broadleaved species in Central Italy, both for their environmental as well as economic value, in connection to coppice exploitation.

In addition, we investigated roe deer use of coppice areas, monitoring the movements of radio-collared roe deer by means of radio-tracking. The aim was to improve the knowledge on roe deer spatial behaviour in the Apennines and to evaluate its impact on vegetative regeneration of coppiced areas. Thus, we performed an analysis on roe deer movements in relation to different phases of coppicing process and related availability of food resources.

\section{Materials and methods}

\subsection{Study site}

In the Apennines, coniferous and deciduous forest stands are present, with the latter being prevalent. In particular, pure and mixed deciduous forests of beech (Fagus sylvatica), chestnut, Turkey oak and downy oak (Quercus pubescens) are present in high percentage (INFC 2007). As regards forest management, the coppice system is mostly adopted in private forests which amount to about two thirds of the total forested area of the Apennines. Coppice areas are mainly concentrated in the lower mountain vegetation belt, where oaks and chestnut are the most common tree species. On the contrary, the high forest system prevails in public areas, which are concentrated in the upper mountain belt and dominated by beech forests. These environments are very important for ungulates (Jedrzejewska and Jedrzejewsky 1998) and represent suitable habitats for roe deer and wild boar (Sus scrofa), whose population densities are the highest among ungulate species in Italy (Apollonio et al. 2010).

The study was carried out in a mountainous area in the province of Arezzo (Tuscany, Italy, $43^{\circ} 48^{\prime} \mathrm{N}, 11^{\circ} 49^{\prime} \mathrm{E}$ ). The site was a protected area "Oasi Alpe di Catenaia" (OAC). Altitude in the area ranged from 330 to $1,514 \mathrm{~m}$ a.s.l. The climate was temperate, with hot and dry summers, and cold and rainy winters. The mean annual rainfall was $1,224 \mathrm{~mm}$, and the mean annual temperature was $9.5^{\circ} \mathrm{C}$. Eighty-four percent of the OAC area was covered in forests, mainly mixed deciduous woods, where the coppice management system was still in use.

The main tree species were chestnut, Turkey oak, and beech. Forest stands were managed by the Regional Forest Service ("Comunità Montana del Casentino") according to a forest management plan. The maintenance of the coppice 
system for obtaining both fire wood and timber wood was allowed in prescribed areas only, mainly concentrated at lower altitudes, where Turkey oak and chestnut prevailed.

The ungulate community in the study area consisted of roe deer and wild boar. Densities of roe deer population was estimated every year, from April to June, with drive census (Table 1). Hunting was strictly forbidden inside OAC, but was practised outside. The natural predators of deer were wolf (Canis lupus) and red fox (Vulpes vulpes).

\subsection{Effects of roe deer browsing on sprouts growth}

The effects of roe deer browsing were evaluated through a 4-year period after the coppicing, in order to analyse the evolution of the degree of browsing through time and to compare the recovering capacity of chestnuts and Turkey oak. The effects of browsing were assessed by means of direct measurements on sprout growth and by means of rapid estimates, which considered the percentage of damaged sprouts. In fact, the reliability of the indirect method was a key issue in order to assess the impact of deer browsing on a large scale, since an analytic and quantitative approach cannot be applied.

In February 2002, six experimental areas, each of the size of $1 \mathrm{ha}$, were established as the representatives of coppice stands. The six stands were at the end of the rotation period, when dominated by Turkey oak or chestnut. A preliminary survey was first carried out in order to determine their representative condition and characteristics before the treatment. The number of shoots and the basal area of chestnut experimental plots ranged from 1,123 to $3,939 \mathrm{ha}^{-1}$ and from 21.7 to $32.3 \mathrm{~m}^{2} \mathrm{ha}^{-1}$, respectively, while the same values ranged from 2,181 to $2,410 \mathrm{ha}^{-1}$ and from 29.0 to $30.0 \mathrm{~m}^{2} \mathrm{ha}^{-1}$ for Turkey oak plots. Subsequently, in March 2002, all six experimental stands were coppiced, with the release of 50-60 standards (reserves) per hectare, in accordance with the procedures and rules used in Italy. In each experimental area, two permanent plots of about $200 \mathrm{~m}^{2}$ of size were established, one of which was fenced (protected, P), while the other was left accessible to deer browsing (non-protected, NP). In each plot, all stools were permanently numbered and surveyed. In order to accurately and quantitatively analyse the effect of roe deer on sprouts and stool development, we recorded number of sprouts, collar diameter $(d)$, total height

Table 1 Population summer densities of roe deer in the study area from 2002 to 2005

\begin{tabular}{lccccc}
\hline Year & 2002 & 2003 & 2004 & 2005 & Mean \pm SE \\
\hline $\begin{array}{l}\text { Number of } \\
\text { individuals per km }{ }^{2}\end{array}$ & 35.3 & 32.8 & 34.9 & 28.0 & $32.8 \pm 1.7$ \\
\hline
\end{tabular}

(h) of sprouts, and number of recently browsed sprouts for each stool. This was carried out at the end of 2002 and then at the beginning and at the end of each growing season, from 2003 to 2005 .

Moreover, in order to obtain rapid estimates of browsing damage, each stool was classified according to the percentage of browsed sprouts, as shown in Table 2. In this way, we established an easy and little time-consuming approach-whose accuracy was tested by means of the observations on sprout growth - to assess and analyse the dynamics of deer browsing with reference to different treatments of sampling plots (fenced and non-fenced plots) and to different tree species (Turkey oak and chestnut). In particular, we compared the percentage of stools in each damage class and calculated a browsing index (BI) as the average damage rank recorded in each sampling plot. In addition, the relationship between BI and growth losses in non-fenced plots was determined by correlation coefficient (Pearson's $r$ ). Specific allometric equations were also elaborated in order to assess the effect of deer browsing on the aboveground biomass of stools and sprouts more precisely. Representative samples of 100 chestnut and Turkey oak undamaged sprouts were collected outside and yet close to the experimental plots. Collar diameter and total height of each sprout were subsequently measured in the laboratory, and so, the average parameters for all the stools were obtained. Later, the sprouts were dried in an air stove at $85 \pm 2^{\circ} \mathrm{C}$ until constant weight was reached. The data obtained were used to elaborate specific allometric relations for predicting woody biomass (dependent variable), based on one independent variable $\left(d^{2} h\right)$, according to a simple linear model $y=a+b x$. Each set of data and the relative allometric equation enabled us to estimate the biomass of each sprout and, consequently, of each stool. The impact of deer browsing was assessed by comparing the data from fenced vs non-fenced stools and differences among years by means of mixed linear model (LME) (SPSS 13.0).

\subsection{Telemetry and roe deer use of habitat}

From March 2002 to March 2005, we captured 62 adult roe deer (26 males and 36 females) using vertical dropnets. All animals were equipped with Televilt VHF

Table 2 Classification and ranking of browsing damage in regard to the percentage of browsed sprouts on each stool

\begin{tabular}{lcc}
\hline Damage class & $\begin{array}{l}\text { Percentage of } \\
\text { damaged sprouts }\end{array}$ & Damage rank \\
\hline No damage & 0 & 0 \\
Slight damage & $<30 \%$ & 1 \\
Medium damage & $30-60 \%$ & 2 \\
Heavy damage & $>60 \%$ & 3 \\
\hline
\end{tabular}


radio-collars and subsequently located by means of discontinuous radio-tracking, using "Televilt RX-8910 HE" and "TRX 1000-S Wildlife Materials" receivers and four-element handheld Yagi antennas. Each month, 12 or more locations were obtained by triangulation for each animal. We distributed telemetry locations uniformly over the day and separated consecutive fixes by an interval of $\geq 12 \mathrm{~h}$ to avoid autocorrelation. Accuracy of fixes was determined in the field by using test transmitters placed in various habitats, resulting with an error polygon of 1 ha. The average error polygon was smaller than the average size of separate vegetation communities, which was relatively large in our study area (mean \pm SE, $216.3 \pm 92.7$ ha), so it was possible to determine roe deer habitat use in this area. For the purpose of this study, we considered only the fixes that were within coppiced areas and grouped them into three periods: before, during, and after the coppicing. We used radio-tracked roe deer data relative the use of two Turkey oak coppiced areas, indicated with abbreviations "C17-1" and "D5-1". All data necessary for the habitat use analysis were obtained and modified with the programme ArcView GIS 3.2.

We calculated the utilisation index of coppiced areas, where differences in roe deer use of each area were assessed using the formula below. For each period (before, during, and after the coppicing), we calculated the average number of fixes per deer in each area, and divided the outcome by the duration of the period (number of months). Duration of the periods was assessed as follows: "before" lasted from the beginning of deer monitoring to the beginning of the coppicing; "during" lasted as long as the coppicing; and "after" lasted from the end of the coppicing to the end of monitoring. We used a chi-square test for statistical analysis: the observed value was assumed to represent the utilisation index for each period, while the expected value was assumed to represent the utilisation index, as assessed throughout the whole study period.

$$
\frac{\sum_{i=1}^{\mathrm{n}} \operatorname{fix}_{i} / \sum_{i=1}^{\mathrm{n}} \text { roe deer }_{i}}{\sum_{x, j, z=1}^{\mathrm{n}} \operatorname{month}_{x, j, z}}
$$

\section{Results}

3.1 Effects of roe deer browsing on sprouts growth

Roe deer impact on the vegetative regeneration of chestnut and Turkey oak stools in non-fenced plots differed during the year immediately after the coppicing as well as in the years after. In fact, 1 year after coppicing, only $30 \%$ of chestnut stools in non-fenced plots were quite damaged, while in Turkey oak, every single stool was severely browsed (Fig. 1a). Four years after the coppicing, 50\% of Turkey oak stools still suffered severely from roe deer browsing, while chestnut plots showed almost no damage (Fig. 1b).

The different level of browsing damage on chestnut and Turkey oak stools was clearly indicated by the browsing index BI (Fig. 2). In non-fenced plots, Turkey oak stools had markedly higher (roughly threefold higher) average BI than chestnut stools. In both species, the BI showed a decreasing trend through the years after the coppicing. However, while in chestnut plots the BI approached zero, it still measured over 0.54 years after coppicing in Turkey oak plots.

Different effects of deer browsing could also be observed in relation to the height of sprouts. Roe deer browsing did not have a significant effect on the height of sprouts in chestnut already 1 year after coppicing (Fig. 3). In contrast, in Turkey oak plots, the height of the sprouts in fenced plots was found to differ from that observed in nonfenced plots according to LME analysis during the whole study period (effects of protection: LME $F_{1,160}=168.31 p<$ 0.001 ; effects of years: LME $F_{3,160}=111.02 p<0.001$; combined effects protection $\times$ years: LME $F_{3,160}=3.52 p=$ 0.021) (Fig. 3). In Turkey oak plots, the height of the sprouts from fenced and non-fenced plots still differed even 4 years after coppicing (Fig. 3).

Differences in the sprout diameter due to the browsing were also assessed. One year after the coppicing, there was

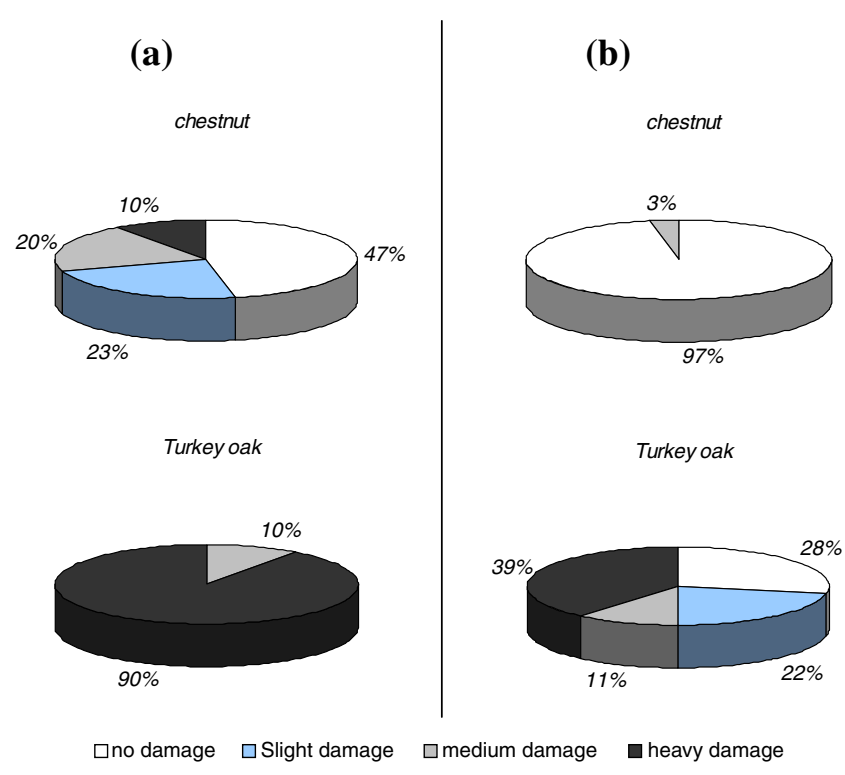

Fig. 1 Effect of roe deer browsing on chestnut and Turkey oak stools 1 year (a) and 4 years (b) after coppicing 


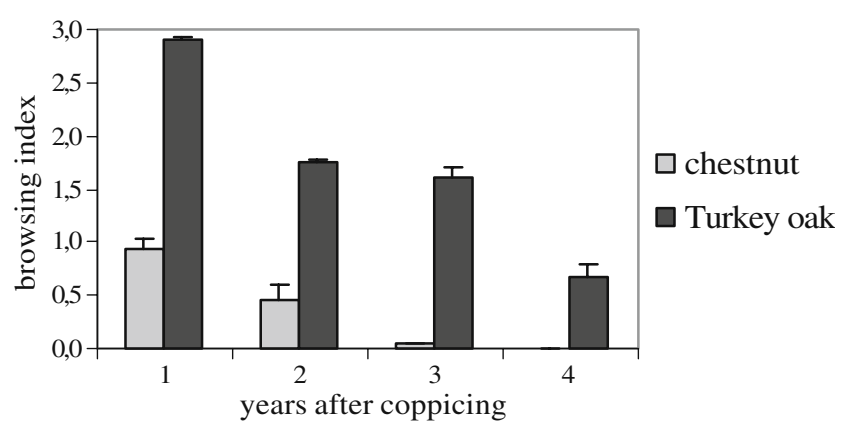

Fig. 2 Comparison of the effect of roe deer on chestnut and Turkey oak sprouts as revealed by browsing index: mean $( \pm \mathrm{SD})$ browsing index through 4 years after coppicing

no significant difference between the diameters of the sprouts from fenced and non-fenced plots in chestnut as well as Turkey oak (Fig. 4). On the contrary, in Turkey oak plots, the mean diameter of the sprouts was significantly smaller in non-fenced plots than in fenced (effects of protection: LME $F_{1,160}=455.61 p<0.001$; effects of years: LME $F_{3,160}=2,982.22 p<0.001$; combined effects protection $\times$ years: $\operatorname{LME} F_{3,160}=256.15 p<0.001$; Fig. 4 ) since the second year after coppicing on.

Number, height, and diameter of sprouts affected the average stool biomass. In chestnut plots, no difference in stool biomass was found between fenced and non-fenced plots, while in Turkey oak plots, the average stool biomass in fenced plots was higher than in non-fenced plots (effects of protection: LME $F_{1,160}=998.57 p<0.001$; effects of years: LME $F_{3,160}=37.58 \quad p<0.001$; combined effects protection $\times$ years: $\operatorname{LME~} F_{3,160}=130.36 p<0.001$; Fig. 5).

Pearson's correlation coefficient between $\mathrm{BI}$ and growth losses, expressed as difference in percent between sprouts height and stools biomass from fenced and non-fenced plots, for chestnut as well as Turkey oak, was calculated. For Turkey oak, we confirmed a significant correlation between $\mathrm{BI}$ and losses in height of sprouts $(r=0.859$; $p=$ $0.006)$, and between BI and losses in biomass of stools $(r=$ $0.659 ; p=0.075$ ).

\subsection{Roe deer use of coppice areas}

The use of coppiced areas by radio-collared roe deer appeared to be more frequent during and after the coppicing. In details, the utilisation index for two Turkey oak stands varied significantly according to the period: during and after the coppicing, roe deer spent more time in the coppiced areas than before $\left(\chi^{2}=12.91 ; d f=2 ; p<0.01\right.$, and $\chi^{2}=6.56 ; d f=2 ; p<0.05$ for the areas "C17-1" and "D5-1", respectively; Fig. 6). The stands were used significantly more frequently during the harvest.

Therefore, we took into account the distribution of fixes in different periods of the day (i.e. night, dawn, daylight, dusk), which showed a more intense use during the night for both Turkey oak stands during the coppicing. In details, in the "D5-1" area, night fixes represented $23.4 \%$ of the total fixes before the harvest, $27.3 \%$ during the harvest, and $0 \%$ after the harvest. In the "C17-1" area, night fixes represented $34.8 \%$ of the total fixes before the harvest, $100 \%$ during the harvest, and $0 \%$ after the harvest.

\section{Discussion}

Our study revealed different levels of roe deer browsing pressure on Turkey oak and chestnut. In particular, damages were more severe in Turkey oak than in chestnut stands; consequently, a high degree of selection of feeding sites was evident.

Some studies pointed out that deer might use woods to a different degree according to their structure and composition. These studies found that most deciduous species were palatable to deer (Gill 1992; Tremblay et al. 2007). We investigated the different use of coppice areas by roe deer, and specifically, only low levels of damage were observed in chestnut coppice where no significant reduction in growth was recorded due to roe deer browsing.

Deer browsing was shown to affect the individual tree survival only to a small extent, especially after its first 5 years of growth (Black et al. 1979). However, different tree species showed retarded recruitment under heavy deer browsing pressure (Mysterud and Ǿstbye 2004; Beguin et al. 2009). Our study showed a high level of roe deer browsing during the first year after coppicing, and its effects gradually decreased through the following years. In
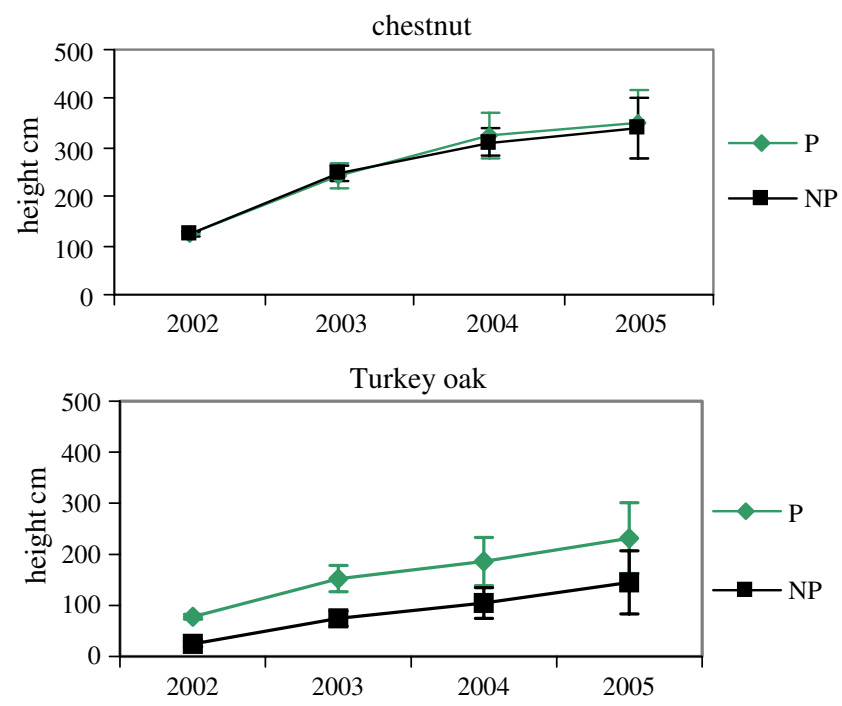

Fig. 3 Mean $( \pm \mathrm{SD})$ height of chestnut and Turkey oak sprouts, protected $(P)$ and non-protected $(N P)$ from roe deer browsing, from 2002 to 2005 

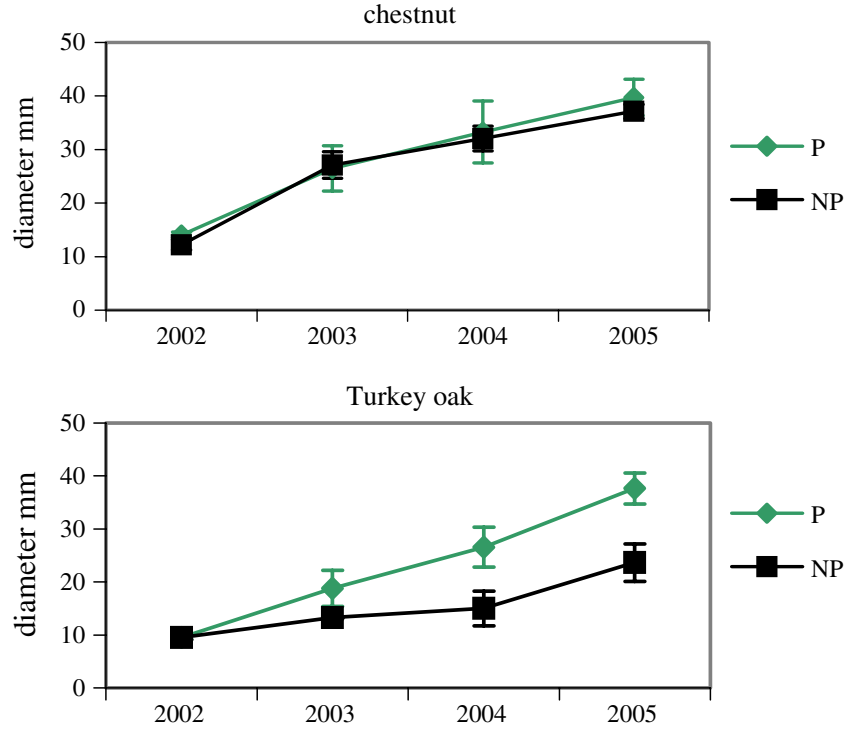

Fig. 4 Mean $( \pm$ SD) collar diameter of chestnut and Turkey oak sprouts, protected $(P)$ and non-protected $(N P)$ from roe deer browsing, from 2002 to 2005

the Turkey oak coppice, both diameter and height of sprouts and consequently stool biomass decreased due to browsing. In the case of those few Turkey oak sprouts that succeeded to grow over the browsing height was the browsing concentrated on the lateral twigs.

Roe deer impact on growth of sprouts was completely different between Turkey oak and chestnut plots. In the first year after coppicing, the browsing index was noticeably lower in chestnut than in Turkey oak stands. Faster growth of chestnut sprouts (height increase of $1 \mathrm{~m} /$ year roughly)
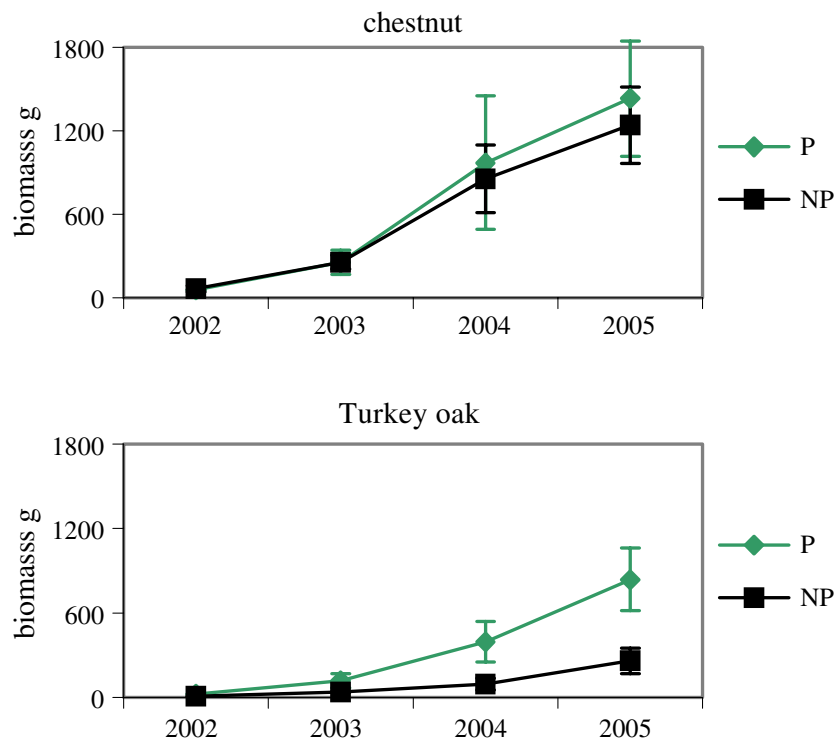

Fig. 5 Mean $( \pm \mathrm{SD})$ biomass of chestnut and Turkey oak stools, protected $(P)$ and non-protected $(N P)$ from roe deer browsing, from 2002 to 2005

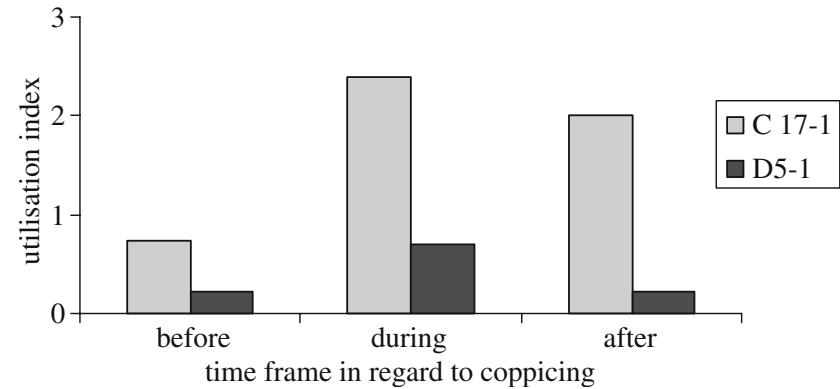

Fig. 6 Utilisation index for the use of two Turkey oak coppice areas (tagged "C17-1" and "D5-1") by radio-collared roe deer in three different periods with respect to wood harvesting (before, during, and after coppicing) from 2002 to 2005

prevented roe deer browsing on chestnut already from the second year after the coppicing. Moreover, the lower level of browsing damage in chestnut stands was most likely connected to roe deer preference for Turkey oak over chestnut. The outcomes were consistent with the findings of previous studies on Quercus spp., which were more susceptible to browsing (Gill 1992; Kuiters and Slim 2002).

Additionally, roe deer were reported to feed highly selectively (Bergman et al. 2005; Moser et al. 2008; Jarni et al. 2004). Given that the selection of browsing sites can be explained by differences in the food quality (Jarni et al. 2004), the different taste of Turkey oak and chestnut sprouts could accordingly likely contribute to the observed browsing pattern. Speculatively, different concentration of tannins in chestnut and Turkey oak may encourage selective feeding. For instance, Bergvall et al. (2006) reported that deer preferred plants with low tannin concentrations. Also, a negative relationship was found between the height and palatability of 1-year-old seedlings (Laitinen et al. 2002). In fact, as pointed out by Ward and Young (2002), severe browsing on sprouts may induce high carbohydrate demands as a growth response. This would consequently limit the production of tannins and increase the palatability of sprouts to deer. On the contrary, plants that are browsed to a lower degree, like chestnut in our study, may produce more tannins, so their palatability to deer even decreases. Moreover, shoots within browsing height were more vulnerable than shoots above the browsing height (Rooke et al. 2004). Thus, all these factors likely contributed to a differential pattern of browsing between Turkey oak and chestnut stands. However, Fickel et al. (1998) pointed out that roe deer unexpectedly showed a high tannin-binding capability, probably due to prolinecontaining enzymes mixed with parotid salivary proteins, which enabled them to hydrolyse and condense tannins. Nevertheless, in the case of choice-like in our studythey most likely choose plants with a lower concentration of tannins. 
The results of detailed analyses of diameter, height, and biomass dynamics and those obtained from an experimental browsing index were strongly in accordance, which supported the reliability of the latter approach. The outcome is relevant; as such, a fast field approach arguably represents a useful management tool (Espleta et al. 2006). Namely, in order to assess the effects of deer browsing on vegetative regeneration on a larger scale, a quick and reliable field approach is necessary since analytic and quantitative approaches cannot be applied.

The radio-tracking data on collared roe deer individuals were consistent with the vegetation survey findings for Turkey oak stands. The number of deer locations inside coppice areas increased above all during as well as after the wood harvesting. During the harvest, high quantities of biomass, e.g. crown foliage, immediately became available for roe deer consumption. Roe deer approached these sites when foresters ceased their daily disturbance and foraged on the foliage. The utilisation index was higher in the period of harvesting and in the following 3 years than in the period before harvesting. This contrasted with the common opinion that ungulates leave the stands during harvest operations because of the disturbance. Our study, on the other hand, provided evidence that roe deer used these areas, however mostly during the night after the cease of forester works, and thus avoided the direct anthropogenic disturbance during the day.

Another important feature of coppice stands is their high vegetation density. This is connected to the visibility and consequently to the possibility for animals to use stands as hiding places. In our study site, the recruitment of sprouts was especially high in the first and second year after coppicing. That is why the middle layer of vegetation was so dense, which consequently represented an optimal environment for hiding fawns, as well as safe resting places for adults (Mysterud and Ims 1999). Indeed, dense coppice stands were selected by roe deer females with fawns as part of their anti-predator strategy (Bongi et al. 2008). On the one hand, our results provided evidence for the importance of Turkey oak coppice as a feeding place and as a shelter for roe deer in our study area. On the other hand, our results confirmed a non-negligible effect of roe deer on vegetative regeneration of Turkey oak. These outcomes highlighted a possible role of roe deer in influencing competition between Turkey oak and chestnut in the first years after coppicing. Similarly, a study from the Netherlands showed that oaks (Quercus robur and Quercus petraea) were outcompeted by beech in the forest canopy due to ungulate browsing pressure (Kuiters and Slim 2002).

When taking into consideration the current roe deer density in the study area and its browsing pressure, one could argue that an increase in roe deer density could influence the Turkey oak regeneration. Several studies found deer density to be positively correlated with occurrence and intensity of browsing damage (Welch et al. 1991; Gill et al. 1996; Putman 1994; Beguin et al. 2009). However, not only deer density but also other ecological factors were crucial to allow the successful regeneration process of forest vegetation (Heuze et al. 2005; Kramer et al. 2006). In our study area, roe deer density has recently been quite stable, and its management plans are designed to maintain it like this. Thus, browsing pressure cannot be expected to decrease.

To sum up, this study showed roe deer preference for coppiced areas and the higher use of them. Forest management plans, based on the coppice system, account for the creation of areas where roe deer gather in higher numbers and animals spend much time foraging, but also resting and hiding. Periodic forest works and harvesting provide large herbivores with resources in terms of available crown foliage, higher number of sprouts, higher grass biomass and variability, and modified hiding as well as resting environment.

One may argue that forest management plans that maintain coppice woods have a positive impact on roe deer population, as they provide a favourable habitat with additional resources, compared to high-forest management. On the other hand, a remarkable presence of roe deer retarded the vegetative regeneration process in Turkey oak coppice. This represents an important issue given that Turkey oak coppices could be seriously damaged by this ungulate species, affecting sprout and shoot development.

Acknowledgements This study was funded by the Ministry of Agriculture and Forest Policy of Italy within the framework of the national research project "The implementation of game management in rural and mountainous areas". We thank to the Arezzo Province and "Comunità Montana del Casentino", especially to Alfredo Bresciani, for logistical support and assistance. We wish also thank all the technicians of Forest Research Centre, all the students and volunteers for their help during field data collection and capture sessions, and two anonymous reviewers for the helpful comments. The English language was reviewed and edited by B. Brandon.

\section{References}

Apollonio M, Ciuti S, Pedrotti L, Banti P (2010) Ungulates and their management in Italy. In: Apollonio M, Andersen R, Putman R (eds) European ungulates and their management in the 21th century. Cambridge University Press, Cambridge, pp 475-505

Bätzing W, Perlik M, Dekleva M (1996) Urbanization and depopulation in the Alps. Mt Res Deve 4:335-350

Beguin J, Pothier D, Prévost M (2009) Can the impact of deer browsing on tree regeneration be mitigated by shelterwood cutting and strip clearcutting? For Ecol Manage 257:38-45

Bergman M, Iason GR, Hester AJ (2005) Feeding patterns by roe deer and rabbits on pine, willow and birch in relation to spatial arrangement. Oikos 109:513-520 
Bergquist J, Orlander G, Nilsson U (2003) Interactions among forestry regeneration treatments, plant vigour and browsing by deer. New For 25:25-40

Bergvall UA, Rautio P, Kesti K, Tuomi J, Leimar O (2006) Associational effects of plant defences in relation to within- and between-patch food choice by a mammalian herbivore: neighbour contrast susceptibility and defence. Oecologia 147:253-260

Black HC, Dimock EJ, Evans J, Rochelle JA (1979) Animal damage to coniferous plantations in Oregon and Washington. 1. A survey 1963-1975. Oreg State Univ Res Bull 25:1-45

Bongi P, Ciuti S, Grignolio S, Del Frate M, Simi S, Gandelli D, Apollonio M (2008) Antipredator behaviour, space use and habitat selection in female roe deer during the fawning season in a wolf area. J Zool Lond 276:242-251

Canham CD, McAninch JB, Wood DM (1993) Effects of the frequency, timing, and intensity of simulated browsing on growth and mortality of tree seedlings. Can J For Res 24:817-825

Cooke AS, Lakhani KH (1996) Damage to coppice regrowth by muntjac deer Muntiacus reevesi and protection with electric fencing. Biol Conserv 75:231-238

Cutini A (2006) Considerazioni sull'assordante silenzio del mondo forestale in merito alla questione dei "Bambi di Alessandria". Forest@ 3:456-458

Drexhage M, Colin F (2003) Effects of browsing on shoots and roots of naturally regenerated sessile oak seedlings. Ann Sci For 60:173-178

Espleta JM, Habrouk A, Retana J (2006) Response to natural and simulated browsing of two Mediterranean oaks with contrasting leaf habit after a wildfire. Ann Sci For 63:441-447

Fickel J, Goritz F, Joest BA, Hildebrandt T, Hofmann RR, Breves G (1998) Analysis of parotid and mixed saliva in Roe deer (Capreolus capreolus L.). J Comp Physiol B 168:257-264

Forsyth DM, Caley P (2006) Testing the irruptive paradigm of largeherbivore dynamics. Ecology 87:297-303

Gill RMA (1992) A review of damage by mammals in north temperate forests: 1 Deer. Forestry 65:145-169

Gill RMA, Johnson AL, Francis A, Hiscocks K, Peacea AJ (1996) Changes in roe deer (Capreolus capreolus L.) population density in response to forest habitat succession. For Ecol Manage 88:31-41

Heuze P, Schnitzler A, Klein F (2005) Is browsing the major factor of silver fir decline in the Vosges Mountains of France? For Ecol Manage 217:219-228

Höchtl F, Lehringer S, Werner K (2005) "Wilderness": what it means when it becomes a reality - a case of study from the southwestern Alps. Landsc Urban Plan 70:85-95

INFC 2007 - Le stime di superficie 2005 - Prima parte. Tabacchi G., De Natale F., Di Cosmo L., Gagliano C., Gasparini P., Genchi L., Scrinzi G., Tosi V. Inventario Nazionale delle Foreste e dei Serbatoi di Carbonio. MiPAF - Corpo Forestale dello Stato Ispettorato Generale, CRA-ISAFA, Trento. http://www.infc.it. Accessed 12 Feb 2010

Jarni K, Robič D, Bončina A (2004) Analysis of the influence of ungulates on the regeneration of Dinaric fir-beech forests in the research site Trnovec in the Kočevje forest management region. Zb gozdarstva lesarstva 74:141-164

Jedrzejewska B, Jedrzejewsky W (1998) Predation in vertebrate communities. Springer, Berlin, p 450

Jorritsma ITM, van Hees AFM, Mohren GMJ (1999) Forest development in relation to ungulate grazing: a modelling approach. For Ecol Manage 120:23-34
Joys AC, Fuller RJ, Dolman PM (2004) Influences of deer browsing, coppice history, and standard trees on the growth and development of vegetation structure in coppiced woods in lowland England. For Ecol Manage 202:23-37

Kay S (1993) Factors affecting severity of deer browsing damage within coppiced woodlands in the south of England. Biol Conserv 63:217-222

Kramer K, Groot Bruinderink GWTA, Prins HHT (2006) Spatial interactions between ungulate herbivory and forest management. For Ecol Manage 226:238-247

Kuiters AT, Slim PA (2002) Regeneration of mixed deciduous forest in a Dutch forest-heathland, following a reduction of ungulate densities. Biol Conserv 105:65-74

Laitinen J, Rousi M, Tahvanainen J (2002) Growth and hare, Lepus timidus; resistance of white birch, Betula pendula, clones grown in different soil types. Oikos 99:37-46

Latham J (1999) Interspecific interactions of ungulates in European forests: an overview. For Ecol Manage 120:13-21

Morellet N, Guibert B (1999) Spatial heterogeneity of winter forest resources used by deer. For Ecol Manage 123:11-20

Morellet N, Gaillard JM, Hewison AJM, Ballon P, Boscardin Y, Duncan P, Klein F, Maillard D (2007) Indicators of ecological change: new tools for managing populations of large herbivores. J App Ecol 44:634-643

Moser B, Schütz M, Hindenlang KE (2008) Resource selection by roe deer: are windthrow gaps attractive feeding places? For Ecol Manage 255:1179-1185

Mysterud A, Ims RA (1999) Relating populations to habitat. Trends Ecol Evol 14:489-490

Mysterud A, Ǿstbye E (1999) Cover as a habitat element for temperate ungulate: effects on habitat selection and demography. Wild Soc Bull 27:385-394

Mysterud A, Ǿstbye E (2004) Roe deer (Capreolus capreolus) browsing pressure affects yew (Taxus baccata) recruitment within nature reserves in Norway. For Ecol Manage 120:545-548

Partl E, Szinovatz V, Reimoser F, Schweiger-Adler J (2002) Forest restoration and browsing impact by roe deer. For Ecol Manage 159:87-100

Putman RJ (1994) Deer damage in coppice woodlands: an analysis of factors affecting the severity of damage and options for management. Q J Forest 88:45-54

Reimoser F, Ellenberg H (1999) Forest management system as a component of ungulate-game pest management with special reference to roe deer and edge effects. In: Cowan PD, Feare CJ (eds) Advances in vertebrate pest management. Filander Verlag, Fürth, pp 219-238

Reimoser F, Armstrong H, Suchant R (1999) Measuring forest damage of ungulates: what should be considered. For Ecol Manage 120:47-58

Rooke T, Danell K, Bergström R, Skarpe C, Hjältén J (2004) Defensive traits of savanna trees - the role of shoot exposure to browsers. Oikos 107:161-171

Tremblay J-P, Hout J, Potvin F (2007) Density-related effects of deer browsing on tree regeneration dynamics of boreal forest. J Appl Ecol 44:552-562. doi:10.1111/j.1365-2664.01290.x

Ward D, Young TP (2002) Effects of large mammalian herbivores and ant symbiont on condensed tannins of Acacia drepanolobium in Kenya. J Chem Ecol 28:921-937

Welch D, Staines BW, Scott D, French DD, Catt DC (1991) Leader browsing by red and roe deer on young Sitka spruce trees in western Scotland. Damage rates and the influence of habitat factors. Forestry 64:61-82 